\title{
ANALYSIS OF FINANCIAL DISTRESS DETERMINANTS AND THE ROLE OF CORPORATE GOVERNANCE FOR RISK MITIGATION ON LISTED INDONESIAN MANUFACTURING COMPANIES: COVID -19 PANDEMIC
}

\author{
Jessica Putri RARASSATI \\ Swiss German University, South Tangerang, Indonesia \\ jessicararassati@gmail.com \\ Yosman BUSTAMAN \\ Swiss German University, South Tangerang, Indonesia \\ Yosman.bustaman@sgu.ac.id
}

\begin{abstract}
The purpose of this research is to examine the impact of COVID-19 on financial distress; additionally, this paper also analyzes the link of financial ratio and corporate governance on financial distress. This study uses panel data regression analysis method to estimate the relationship between variables. Financial ratios used in this study are Return on Equity (ROE), Debt to Asset Ratio (DAR) and firm size, meanwhile several corporate governance measurements that are applied in this research consist of institutional ownership, commissionaires independent and board size. The measurement will also be aggregated into its sub-sector which consists of Consumer Goods Industry (CGI), miscellaneous industry and basic and chemical industry. It is found that, COVID-19 pandemic statistically impacted financial distress of manufacturing companies in Indonesia as it is proven by T-Test and also regression analysis method. The result reveals that Debt to Asset (DAR) which is the measurement of leverage owned by company, positively affected financial distress of manufacturing companies in Indonesia. The greater the leverage, the greater the risk of financial distress. Despite the discrepancy with previous studies results, the result shows that the numbers of commissionaires independent on manufacturing companies in Indonesia pose significant positive effect on financial distress. Action taken by Chief of Manufacturing companies in Indonesia during this COVID-19 crisis impact the survival of company. Manufacturing companies need to mitigate risk by maintaining higher profitability (ROE) and asset as measured by firm size, lowering debt value. On corporate governance site, companies need to consider limiting the number of independent commissionaires leading the company and gaining more intuitional investor.
\end{abstract}

Keywords: Financial Distress; Corporate Governance; Financial Ratio; Manufacturing Companies; COVID-19 DOI: https://doi.org/10.24818/beman/2021.S.I.2-14 


\section{INTRODUCTION}

The world is facing the existence of the corona virus (COVID-19) pandemic which has prompted a tremendous financial loss for a large number of organizations and business over the globe. Due to the COVID-19 pandemic, the IMF (International Monetary Fund) lowered its forecast for the development of the global economy, thereby reducing the previous forecast into genuine uncertainty. Global recession has predicted by IMF to be as bad as global financial crisis on 2007-2008 and then will start to recover again on 2021 (Georgieva 2020). Governments have set serious limitations on firms in different enterprises, to obey the social distancing and health protection and closing some non-essential business in some countries. This policy will depend on the country industrial situation.

Meanwhile, in the context of Indonesia's economy, the COVID-19 pandemic has also had a significant impact on reducing Indonesia's economic growth. Indonesia has entered a stage of economic recession. One of the effects of the economic recession is the possibility of company bankruptcy due to the company's inability to sell the products, resulting in a decline in company profits and disruption of company operations (Achim, Mare, and Borlea 2012; Smrčka, Arltová, and Schönfeld 2013). Empirical research shows that under a given financial situation, the incidence of bankruptcies during a recession has increased significantly (Taffler 1983).

On June 2020, Indonesian Minister of Industry stated that some of manufacturing industries such as, steel industry, MRO (Maintain, Repair and Overhaul) industries, cement, ceramics and glass industries, textile industry, machinery and heavy equipment industry, furniture and handicraft industry, have been hit hard by the COVID-19 pandemic. On the other hand, by 2019, manufacturing sectors accounted for the largest proportion of Indonesia's GDP.

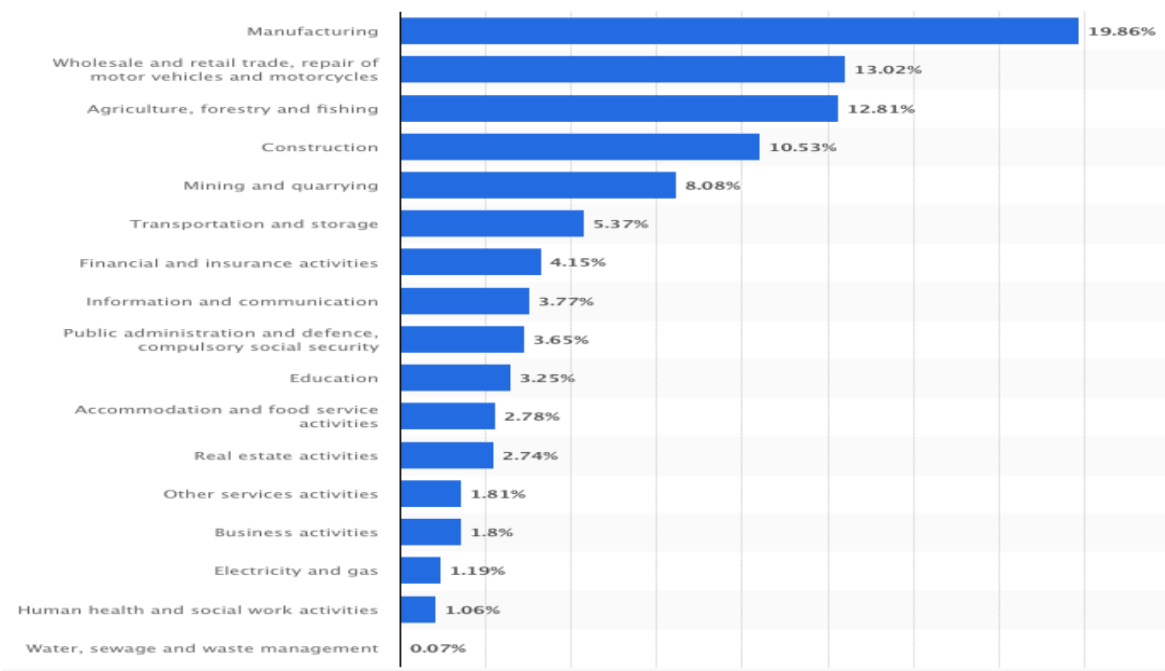

FIGURE 1. INDONESIA CAPITAL SHARES ON GDP BY SECTORS, 2019 
Early prediction of bankruptcy is a needed tool to prevent company's failure, and predictive tool of financial distress is needed for companies. Altman Z-Score is one of financial distress prediction tools, found by Edward Altman (1986) and has been widely used to identify financial distressed companies in many industries across countries. Possibility of company bankruptcy is affected by financial ratios. This is as stated in the research by Thim et al., (2011) that pointed out that profitability, liquidity, and growth and risk are considered important and negatively correlated with financial distress while solvency and company size are negatively correlated on Malaysia manufacturing firms.

Beside financial ratios, previous studies (Altman et al. 2017; Liang et al. 2016) stated that combining financial ratio and non-financial ratio to measure financial distress is effective on predicting bankruptcy risk of firms. Precisely, Liang et al., (2016) stated that a better predictor of bankruptcy to combine financial ratios and corporate governance indicators than to use financial ratios and corporate governance indicators alone.

Previous studies have been conducted to indicate financial distress on Indonesian Manufacturing Industry. Lestari (2020) conducted research of financial distress on manufacturing companies based on data from 2012 to 2016 on Indonesia Stock Exchange, variables used are debt, liquidity, solvency, profitability and activities of Indonesian manufacturing companies. Moreover, Hanani \& Dharmastuti (2015) predicted the possibility of bankruptcy in the consumer goods sectors at the Indonesian Stock Exchange. They found that commissioners independent and the board number which are the corporate governance mechanism had a significant positive impact on the potential for bankruptcy. Potential of bankruptcy measurement used by the authors is Altman Z-Score (1968). However, there are some gaps that this study is going to fill in from the previous scholars. Our research considers COVID-19 as one of explanation variable. In addition, financial ratio and corporate governance mechanism are combined in this study, and the measurement of manufacturing companies is aggregated into three sub-sectors.

This research found that, leverage is the best financial ratio predictor on the financial distress of Indonesian manufacturing company, as well on its three sub-sectors. The greater the value of the ratio will indicate that companies have high value of debt. The high valuation debt against a percentage of assets often means a high risk that the assets utilized by the firm cannot offset the entire debt. This study also found that the greater number of commissioners independent will increase the likelihood of financial distress on manufacturing companies in Indonesia. Independent commissioners is claimed to possess a higher tendency to ensure transparency on previous research (Ajinkya, Bhojraj, and Sengupta 2005). Despite the discrepancy with previous studies results, arguing that independent commissioners have 
positive effects on the company's success or worth, a variety of experts have clarified why often independent commissioners could increase a company's likelihood to fall on bankruptcy. Fich\& Slezak (2008) reported that although independent commissioners enable better supervision, when financial distress is factored in the analysis, non-independent commissioners might have a greater motivation to resolve financial distress due to the higher probability of bankruptcy.

The purpose of this research is to examine financial distress of a company in times of COVID-19 pandemic, and to determine the financial ratio estimator and corporate governance mechanism that affect financial distress, on Indonesian manufacturing companies. The data was taken from Q4 2018 to Q2 2020, and will be divided to terms, before and during COVID-19 pandemic. Financial ratios that are used in this research are profitability, leverage and firm asset. Meanwhile, corporate governance observed in this study are, institutional ownership, board size and commissioner independent. In addition, to recognize the symptoms of financial distress long before the liquidation disaster begins. For regulators such as the OJK IDX, and $\mathrm{BI}$ can be used as reference material in deciding rescue policies for companies whose positions are threatened with bankruptcy due to the COVID-19 Pandemic, such as providing credit restructuring policies to companies experiencing financial distress problems. The essential purpose of the financial crisis prediction model is to collect signs as early as possible so that financial reconstruction can begin in time (Ashraf, G. S. Félix, and Serrasqueiro 2019).

The paper is structured as follows. In the next section the literature that is relevant to our modelling approach is discussed. The database and measure of outcomes variables are described on the next chapter. The estimation methodology is discussed along with analysis, results and conclusions.

\section{LITERATURE REVIEW}

\subsection{Covid-19 Impacts on Global and Indonesian Economy}

The Organization for Economic Cooperation and Development (OECD) and the International Monetary Fund (IMF) have warned that the economic impact of the virus is already greater than that of the global financial crisis of 2008(OECD 2020; Parliament et al. 2011). The United Nations (UN) also expects that the flow of unfamiliar direct speculation may be between $30 \%$ and $40 \%$, causing further damage to lowpaid countries (Ezalia et al. 2020). The economic downturn has disastrous consequences for business growth and profitability worldwide. In particular in the administrative, friendly and assembly sectors, the loss of talented human capital and revenue are falling sharply.

Indonesian economy has been impacted by COVID-19 pandemic. Transport, tourism, industry, health and other sectors are impacted. Different countries have adopted "lock down" arrangements to prevent 
Rarassati, J.P. \& Bustaman, Y.

the further spread of COVID-19, with the purpose of disrupting financial activities and squeezing the development of world currencies in subsequent financial developments, including Indonesia. The downturn of GDP in the first and second quarters that tends to decline is inseparable from the influence of the corona virus (COVID-19) pandemic which has lasted long.

\subsection{Financial Distress}

Financial distress is the first sign of bankruptcy. The ambiguity of the sustainability of the business in the future suggests this (Zmijweski 1984). Altman on 1968 pioneered the use of a multivariate tool, called the Z-Score that forecast the probability for bankruptcy. The model displayed strong predictive ability in financial crisis firms, as calculated by Z-Score. There are also other studies that have developed similar predictive models using different sets of financial ratios(Lau 1987; Ohlson 1980; Zmijweski 1984), but ZScore that was pioneered by Altman still considered as the best predictive calculation for financial distress. Recently, the Z-score model has stood the test and is still quite important to the corporate world today. The determinants of the Altman Original Model (1968) are used in this analysis as the calculation of the financial ratio to predict bankruptcy, since this study includes the measurement of Indonesian manufacturing firms. In addition, some researchers who calculate the prediction of bankruptcy of manufacturing firms have also used the original Altman Z-Score model (1968) in other countries (Imelda and Alodia 2017; Steinker, Pesch, and Hoberg 2016)

\subsubsection{Financial Ratio and the Impact on Financial Distress}

Financial ratio that are observed in this study are profitability which will be measured using Return On Equity (ROE), leverage ratio which will be measured using Debt to Asset Ratio (DAR) and firm size which will be measured using natural logarithm of Total Asset. Profitability determined by equity return was often seen as a consideration deciding when a company would become financially troubled. The higher companies' profitability indicates a better efficacy of firms on generating income by their activities on their business. Previous research shown results that ROE has significant negative effect on financial distress, it shows the higher profit a company has, will result on the less likelihood of a firm to go bankrupt (Fredrick 2019; See Liang and Pathak 2019; Tesfamariam 2014; Thim, Choong, and Nee 2011).

Leverage is the fund source debt the business utilizes to manage its investments outside the cash or stock source. Analysis performed before, (Altman et al. 2016; Thim, Choong, and Nee 2011) found a positive impact on the state of financial distress, which means the greater the leverage will increase the possibility on financial distress of a firm.

Big businesses typically have greater access to capital markets, as it is simpler to increase funding with reduced rates and lower restrictions than smaller firms, which indicates the dependence on internal funds 
would decline with the company's rising scale. Moreover, firm which have large size are often not born at base. It usually takes a lot of time before an organization becomes a major company (Akpinar 2017; Tesfamariam 2014).

\subsubsection{Corporate Governance and the Impact on Financial Distress}

Corporate governance is a collection of processes aimed at reducing the costs of agencies arising from the presence of data asymmetry. Attribute means that good corporate governance is adopted by the corporation from an organizational framework that accommodates accountable, transparent and unbiased oversight mechanisms. Liang et al., (2016) who discovered in their analysis that the model of bankruptcy prediction that blends financial ratio (FR) and corporate governance practices (CGP) is more precise than the one that only uses either FR or CGP. Corporate governance mechanism that are observed in this study are, institutional ownership, commissionaires independent and board size.

Institutional ownership is the portion of stocks that is owned by any organizational or corporate institution (David, Kochhar, and Levitas 1989). Institutional investors have a significant role to play in corporate governance, especially in their ability to track, collect and influence company policies and results (Guo and Qi 2008) and provide better monitoring for companies in times of need.

An independent commissionaire is not associated with the controlling owners, administrators and or other board commissioners and may not take up the position of director at any company which is affiliated with that business. In contrast to the overall number of commissioners within the board, the board's independence is the percentage of elected commissioners. Independent commissioners tend to provide better monitoring for financially-distressed companies because of their smaller probability of having conflicts of interest (Fich and Slezak 2008).

The board size applies to the number of members of the board. Larger number of boards might have problems of balance, resulting in greater control by their representatives to satisfy their personal needs to the disadvantage of the company's general interest. This is also supported by current finding in Indonesia from consumer good sectors that board size is positively affected bankruptcy risk (Hanani and Dharmastuti 2015)

\section{RESEARCH METHODS}

\subsection{Data}

The data gathered from 58 manufacturing companies in Indonesia that conclude of 10 miscellaneous 28 consumer goods industries, and 20 chemical industries. In this analysis, sampling with the approach of purposive sampling is performed with non-probability. The sample in this study was manufacturing 
Rarassati, J.P. \& Bustaman, Y.

ANALYSIS OF FINANCIAL DISTRESS DETERMINANTS AND THE ROLE OF CORPORATE GOVERNANCE

FOR RISK MITIGATION ON LISTED INDONESIAN MANUFACTURING COMPANIES: COVID-19 PANDEMIC

company in the period of Q4 2018-Q2 2020 that meets the criteria. The quantitative methodology was taken in this study and used secondary data. Data are collected using various sources of financial reports and database (IDX (Indonesia Stock Exchange), Yahoo Finance, Bloomberg Data). Financial report of the firms also limited from Q4 2018 to Q2 2020.

\subsection{Empirical Model}

The study utilized the three financial ratios and three governance mechanisms as the independent variables and the Altman Z-Score as the dependent variable to estimate the following regression:

$$
\begin{aligned}
Z_{\text {SCORE }}=\alpha+\beta_{1} D_{\text {it }}+ & \beta_{2} R_{\text {ROE }}+\beta_{3} \text { DAR }_{\text {it }}+\beta_{4} \text { FIRMSIZE }_{\text {it }}+\beta_{5} I N S O W N_{\text {it }}+\beta_{6} I N D C O M_{\text {it }} \\
& +\beta_{7} \text { BOARDSIZE }_{\text {it }}+e
\end{aligned}
$$

The model will be used to measure dependent variable on all manufacturing industries sector (MFI) (1), miscellaneous industries sub-sector (MSC) (2), consumer goods industries sub-sector (CGI) (3), and chemical industries sub-sector (CMI) (4).

TABLE 1. OPERATIONALIZATION OF RESEARCH VARIABLES

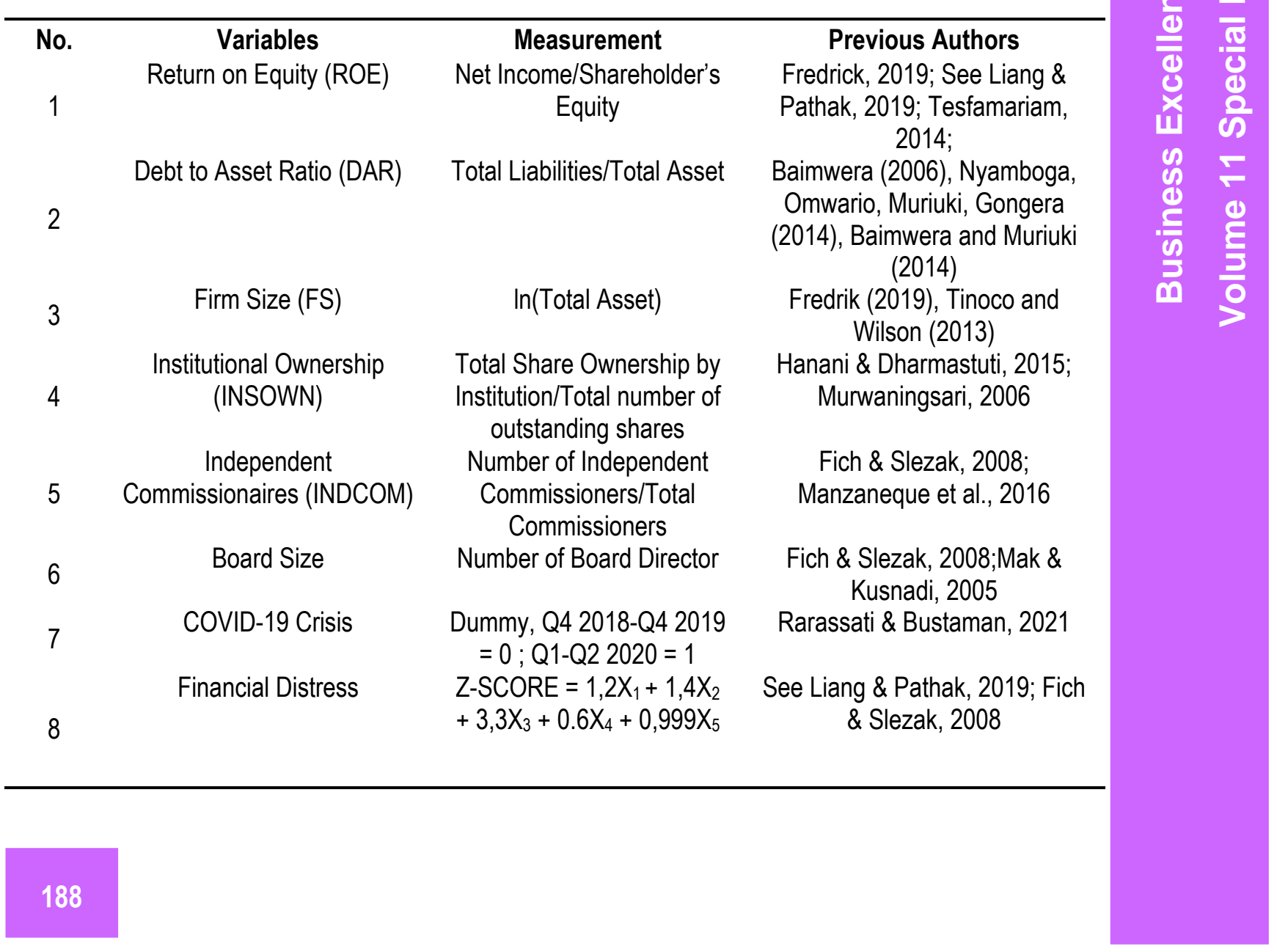


Rarassati, J.P. \& Bustaman, Y.

ANALYSIS OF FINANCIAL DISTRESS DETERMINANTS AND THE ROLE OF CORPORATE GOVERNANCE FOR RISK MITIGATION ON LISTED INDONESIAN MANUFACTURING COMPANIES: COVID-19 PANDEMIC

Source: Author's conclusion

\section{FINDING AND RESULT}

TABLE 2. Z-SCORE TREND ANALYSIS

\begin{tabular}{|c|c|c|c|c|c|c|c|}
\hline \multirow{2}{*}{ Sectors } & \multicolumn{7}{|c|}{ Period } \\
\cline { 2 - 8 } & Q42018 & Q12019 & Q22019 & Q32019 & Q42019 & Q12020 & Q22020 \\
\hline MFI & 5,559 & 5,319 & 5,191 & 5,390 & 5,152 & 4,271 & 4,891 \\
\hline MSC & 3,029 & 3,078 & 3,097 & 3,048 & 3,076 & 2,615 & 2,764 \\
\hline CGI & 7,439 & 7,244 & 6,938 & 7,349 & 6,872 & 5,649 & 6,712 \\
\hline CMI & 4,191 & 3,746 & 3,792 & 3,820 & 3,783 & 3,170 & 3,407 \\
\hline
\end{tabular}

Source: Author's Calculation

TABLE 3. PAIRED T-TEST ANALYSIS

\begin{tabular}{|c|c|c|c|c|}
\hline Sectors & t-stat & $\begin{array}{c}\text { t-critical two } \\
\text { tail }\end{array}$ & Condition & Conclusion \\
\hline MFI & 3,031 & 2,003 & T1 Accepted & Significant decrement \\
\hline MSC & 2,332 & 2,263 & T1 Accepted & Significant decrement \\
\hline CGI & 2,090 & 2,052 & T1 Accepted & Significant decrement \\
\hline CMI & 2,290 & 2,093 & T1 Accepted & Significant decrement \\
\hline
\end{tabular}

Source: Author's Calculation

Tables from trend analysis show that there was decrement on Z-SCORE, which shows that it is more likely form a firm to undergo financial distress. It is also proven by Paired T-Test analysis that shows the decrement on every sub-sectors and manufacturing sector as whole, is significant. From the data, it can be concluded that the existence of COVID-19 pandemic affected financial distress of companies on manufacturing sectors.

TABLE 4. REGRESSION ANALYSIS RESULT

\begin{tabular}{|c|c|c|c|c|c|c|c|c|c|}
\hline \multirow{2}{*}{\multicolumn{2}{|c|}{ Z-SCORE }} & \multirow{2}{*}{\multicolumn{2}{|c|}{$\frac{\text { Model 1 }}{\text { All Manufactures }}$}} & \multirow{2}{*}{\multicolumn{2}{|c|}{$\frac{\text { Model } 2}{\text { Basic and Chemical Industry }}$}} & \multirow{2}{*}{\multicolumn{2}{|c|}{$\begin{array}{c}\text { Model } 3 \\
\text { Miscellaneous Industry }\end{array}$}} & \multirow{2}{*}{\multicolumn{2}{|c|}{$\begin{array}{c}\text { Model } 4 \\
\text { Consumer Goods Industry }\end{array}$}} \\
\hline & & & & & & & & & \\
\hline \multirow[t]{2}{*}{ Dummy } & Coeff & -0.8522 & -0.8437 & -0.5718 & -0.5916 & -0.5199 & -0.4131 & -1.0344 & -1.081 \\
\hline & Prob & $0.0000^{* * *}$ & $0.0000^{* * *}$ & $0.0006^{* * * *}$ & $0.0003^{* * * *}$ & $0.0234 * *$ & $0.0497 * *$ & $0.0004 * * *$ & $0.0002 * * *$ \\
\hline \multirow[t]{2}{*}{ ROE } & Coeff & 2.0688 & 2.1516 & 11.2087 & 10.8256 & 1.7705 & 7.3826 & 2.1805 & 2.3987 \\
\hline & Prob & $0.0081 * * *$ & $0.0062 * * *$ & $0.0987 *$ & 0.1084 & 0.8402 & 0.3567 & $0.0393 * *$ & $0.0226^{* *}$ \\
\hline \multirow[t]{2}{*}{ DAR } & Coeff & -15.3644 & -15.0000 & -10.30144 & -10.5600 & -6.7680 & -5.6300 & -18.6070 & -18.2251 \\
\hline & Prob & $0.0003^{* * *}$ & $0.0000^{* * *}$ & $0.0000^{* * *}$ & $0.0000^{* * *}$ & $0.0685^{*}$ & $0.0250 * *$ & $0.0000^{* * *}$ & $0.0045^{* * *}$ \\
\hline \multirow[t]{2}{*}{ FIRMSIZE } & Coeff & 0.7008 & 0.7788 & 0.4125 & 0.6010 & -0.5765 & 0.1776 & -0.5814 & 0.7104 \\
\hline & Prob & $0.0285^{* *}$ & $0.0046^{* * * *}$ & 0.1310 & $0.0072 * * *$ & 0.5137 & 0.5776 & 0.6753 & 0.1763 \\
\hline \multirow[t]{2}{*}{ INSOWN } & Coeff & 3.3327 & & -0.5756 & & 5.3491 & & 3.4041 & \\
\hline & Prob & $0.1000^{*}$ & & 0.7309 & & $0.0864 *$ & & 0.7650 & \\
\hline \multirow[t]{2}{*}{ INDCOM } & Coeff & -4.2530 & & 0.9948 & & -2.9613 & & -8.5862 & \\
\hline & Prob & $0.0203 * *$ & & 0.5686 & & 0.5222 & & $0.0128^{* *}$ & \\
\hline \multirow[t]{2}{*}{ BOARDSIZE } & Coeff & 0.0858 & & 0.2220 & & 0.1493 & & -0.0546 & \\
\hline & Prob & 0.6263 & & 0.2314 & & 0.6100 & & 0.8784 & \\
\hline \multicolumn{2}{|c|}{ R-Squared } & 0.2211 & 0.2015 & 0.3098 & 0.2984 & 0.9407 & 0.1334 & 0.9276 & 0.2252 \\
\hline
\end{tabular}


Rarassati, J.P. \& Bustaman, Y.

$\left({ }^{* *}\right): 1 \%$ significant level $\left({ }^{* *}\right): 5 \%$ significant level $\left({ }^{*}\right): 10 \%$ significant level

\section{Source: Author's Calculation}

Based on table regression above, it can be taken that dummy variable which is the existence of COVID19 has significantly negative relation with Z-SCORE. Therefore, the existence of COVID-19 pandemic has been proven by statistic measurement bring manufacturing industries to a condition of higher probability on facing bankruptcy.

The impact of COVID-19 in Indonesian manufacturing might due to the reducing of purchasing power on this pandemic condition, people tend to save more of money, because people get prepared of being jobless since many companies are hardly hit by this condition. Some operation factors might also be the reason why COVID-19 negatively affect bankruptcy risk, supply chain bottleneck due to close border on some exporting countries, for example, China and Europe. Factories get more of attention from SATGAS (SatuanGugusTugas) COVID-19 since they became one of some huge cluster transmissions in Indonesia, factories face reality to choose between reducing their operator which means it also reduces time operation and availability of finish goods to sell, or spend more of money to conduct regular COVID19 test and evaluation of their workers which need extra much money to spend.

\section{DISCUSSION}

\subsection{Analysis impact of Financial Ratio on Financial Distress of Listed Indonesian Manufacturing Companies}

Return on Equity

In this research return on equity shows positive relationship with Z-SCORE, which means if ROE rises by 1 percent will increase the Z-SCORE based on the value of coefficient beta depends on the sectors of company measured in this study. Therefore, when indicating financial distress, ROE will have negative relation to financial distress, the higher ROE, will impact on the decreasing likelihood of firm to go bankrupt. The result is significant when it is measured on all manufacturing industries and when $\mathrm{CGI}$ and CMl are measured.

High ROE means, companies are able to generate return or profit from the investment of their shareholders that are put on their company. Strong corporate development would offer stakeholders a signal (Signaling Theory) that the business has sustained and has continued to expand. High business development would prove that the organization is stable and not in disarray (financial distress) (Restianti and Agustina 2018). More effective control of investments by owners will deliver greater profits and 
optimum utilization of funds. Manufacturing companies need to put their concern on Return on Equity and how to manage it while running their company, in order to avoid bankruptcy of their companies. Debt to Asset Ratio (DAR)

DAR has significant positive relationship with financial distress. This result is supported by previous research that have been conducted in manufacturing companies also, whether it is from different countries, or also companies in Indonesia within different time range (Akpinar 2017; Fredrick 2019; Kristanti, Rahayu, and Huda 2016; Madaleno and Bărbuţă-Mişu 2019; Tesfamariam 2014; Thim, Choong, and Nee 2011). The greater the leverage, the greater the risk of financial distress.

The principle of the pecking order was also used to describe whether a corporation is failing financially. The inference of this hypothesis is that increasing usage of foreign sources of funds will impact the business adversely if not wisely utilized and the risk of financial distress of businesses is increased. Thus, in this research, all manufacturing companies need to put concern on their debt value. The greater the leverage, the greater the risk of financial distress.

Firm Size

Firm size is the natural logarithm of total asset. When measuring firm size as determinant of bankruptcy risk on all manufacturing firms, the result shows that firm size has significant positive relation with ZSCORE. This means the bigger the assets that the firm has, will increase the number of Z-SCORE and decrease the possibility of manufacturing companies to go bankrupt. Meanwhile this result is inconsistent, when being disaggregated to three sub-sectors, firm size is only being significant estimator of bankruptcy risk on all manufacturing when measured altogether. The insignificance might happen probably because even when the companies do not have a huge amount of total asset, they have strong capital or investing so that they may subsidize one another division to avoid bankruptcy.

\subsection{Analysis the Impact of Corporate Governance on Financial Distress of Listed Indonesian}

\section{Manufacturing Companies}

\section{Institutional Ownership}

In this research, institutional ownership is found to have significant positive relation with Z-SCORE on manufacturing companies as whole, this might explain that the higher ownership belongs to institution will affect companies to less likely to go bankrupt. Institutional who own shares are advised to track management to enhance their long-term efficiency to avoid the possibility of financial distress. Institutional owners are also called resource investors. This is in line with some findings on previous research, institutional investment ratio would greatly impact the company's stock valuation. The foundation of this claim is that the broader the institutional ownership, the more powerful the management control process 
Rarassati, J.P. \& Bustaman, Y.

is. Institutional ownership as one of the factors in the organizational management system serves as a monitoring function for the potential determinants of the corporation's investment. A firm investment equates prospects, strategies or ventures to accomplish its aims, including profitability. The businesses with significant investment opportunities demonstrate their promising future prospects and therefore have a good effect on the valuation of the business and will be safer from bankruptcy potential.

Therefore, in order to avoid bankruptcy of manufacturing companies need to boost their performance to gain institutional investors' attention, by being more innovative which shows that the company is getting more concerned on their long-term shelf life in the industry, and also to companies who prioritize their liquidity. Moreover, as reported by Klempner, Skovira and Tarmowski (2020), who interviewed some institution investors taking consideration of their type of attractive company in the midst of COVID-19 crisis are those companies which maintain shareholder trust, including members of board, employees, financial liquidity, business continuity and performance of investment.

In addition, there is inconsistent result when measuring three sub-sectors on manufacturing industries. Based on previous findings, it is presumed that Indonesian institutional investors on consumer goods industry and chemical industries are not as active as expected in the management of firms. This is sometimes caused by the fact that most institutional investors are index funds that are more concerned in attaining high returns for the index fund holders than making the company perform well (Fich and Slezak 2008).

\section{Independent Commissioners}

The greater number of commissioners independent will increase the likelihood of financial distress on manufacturing companies. Despite the discrepancy with previous studies results, arguing that independent commissioners have positive effects on the company's success or worth, a variety of experts have clarified why often independent commissioners could increase a company's likelihood to fall on bankruptcy. Previous researches that the degree of engagement shared with non-independent commissioners provides them with deeper information, insight and insights on the management and priorities of the companies under which they operate relative to independent commissioners.

Independent commissioners are rumored to allow improved oversight before a majority of them are working. After the amount is hit, adding independent commissions could have a detrimental effect on the company.

Besides, when divided into three sub sectors number of independent commissioners only significant for consumer goods industry. For chemical and miscellaneous industry, the regression analysis does not show any significance. This analysis struggled to show the independent commissioner's effect on the likelihood of financial crisis at those sub sectors. This is exacerbated by the comparatively limited number 
of independent commissioners. This limited share of independent commissioner leaves independent commissioner unwilling to control management practices. The independent commissioner works and duties as the decision-making balance is not firm, therefore it could not affect management's decisions. Other causes that trigger outcome discrepancies are attributed to the presence of an independent commissioner solely as a formality. Under the statute, the required number of independent commissioners is around $30 \%$ of all commissioners, but the findings revealed that independent commissioners have little impact on the likelihood of financial distress. It suggested that to satisfy the rule, the presence of an impartial commissioner in the company is just a formality. Even some of manufacturing companies in Indonesia still control by family members as the commissioners, therefore the existence of independence commissioner is not significant because people who are not family member will not have power.

\section{Board Size}

In this research the result is consistent, that board size has no significant relationship with Z-SCORE, which means it does not determine the likelihood of manufacturing firms to go bankrupt. Therefore, it can be concluded that, the number of directors in a company does not really matter, what matters possibly, their knowledge and their character on handling the company, being a good decision maker and cooperative on leading the company, doing good monitoring on their companies. It needs further research on what criteria need to be owned by board directors to have a good leadership.

\section{CONCLUSION}

COVID-19 pandemic has affected financial distress likelihood of manufacturing companies in Indonesia, included all sectors in manufacturing industries. Return on Equity (ROE) which is the measurement of profitability, Debt to Asset Ratio (DAR) which is the measurement of leverage, Institutional ownership which is stock belongs to institution and firm size have significant positive relationship with ALTMAN ZSCORE, which means the increment of ROE will decrease likelihood of companies to go bankrupt. Independent commissionaires show negative relationship with ALTMAN Z-SCORE, which the higher number of independent commissionaires in manufacturing companies in Indonesia will increase financial distress likelihood of companies while board size shows no significant result.

Based on this research, in order to mitigate risk, manufacturing industries need to maintain high ROE, lower debt value and high number of assets. In addition, gaining more institutional investor by more innovative, prioritize liquidity and mind business continuity, because institutional investor will consider the long-term life of company, and manufacturing companies need to understand the limit of independent commissionaire and the quality needed by the company. 
There are some limitations that require improvement in this research. These limitations include, the period of COVID -19 pandemic, the number of sample is limited on manufacturing companies, the model only used Z_SCORE to measure financial distress, and the corporate governance only use institutional ownership, independent commissionaire and board size. Further research need to be conducted on measuring the long period of COVID-19 pandemic to examine more on impact of independent variables to financial distress during COVID-19 pandemic. Sampling can also be taken broader, other than manufacturing companies. Future studies are also expected to use other financial distress prediction that rarely been used and use other corporate governance mechanism to clearly examine the impact of corporate governance on financial distress.

\section{REFERENCES}

Achim, M. V., Mare, C., and Borlea, S. (2012). A Statistical Model of Financial Risk Bankruptcy Applied for Romanian Manufacturing Industry. Procedia Economics and Finance 3(December): 132-37. http://dx.doi.org/10.1016/S2212-5671(12)00131-1.

Ajinkya, B., Sanjeev, B., and Partha, S. (2005). The Association between Outside Directors, Institutional Investors and the Properties of Management Earnings Forecasts. Journal of Accounting Research 43(3): 343-76.

Akpinar, O. (2017). Factors Affecting Bankruptcy Risk: An Application on Borsa Istanbul. Economic and Social Development (Esd) (April): 569-75.

Altman, E. I., Małgorzata, I.-D., Erkki, K., Laitinen, and Arto, S. (2017). Financial Distress Prediction in an International Context: A Review and Empirical Analysis of Altman's Z-Score Model. Journal of International Financial Management and Accounting 28(2): 131-71.

Ashraf, S., Elisabete, G. S., and Zélia, S. (2019). Do Traditional Financial Distress Prediction Models Predict the Early Warning Signs of Financial Distress?, Journal of Risk and Financial Management 12(2): 55.

David, P., Rahul, K., and Edward, L. (1989). Academy of Manttgement Loumal IgS8. 41(2): 20-20.

Ezalia, E et al. (2020). “No 主観的健康感を中心とした在宅高齢者における健康関連指標に 関する共分散構造分析Title." Orphanet Journal of Rare Diseases 21(1): 1-9.

Fich, E. M., and Steve. L. S. (2008). Can Corporate Governance Save Distressed Firms from Bankruptcy? An Empirical Analysis. Review of Quantitative Finance and Accounting 30(2): 225-51.

Fredrick, I. (2019). Firm Specific Determinants of Financial Distress: Empirical Evidence from Nigeria. Journal of Accounting and Taxation 11(3): 49-56.

Georgieva, K. (2020). Beyond the Crisis. Finance and Development 57(2): 10-11.

Guo, B. N., and Feng, Q. (2008). Alternative Proofs for Inequalities of Some Trigonometric Functions. International Journal of Mathematical Education in Science and Technology 39(3): 384-89.

Hanani, R. T., and Dharmastuti, C. (2015). How Do Corporate Governance Mechanisms Affect a Firm's Potential for Bankruptcy?, Risk Governance and Control: Financial Markets and Institutions 5(1): $61-71$. 
Imelda, E., and Clara, I. (2017). The Analysis of Altman Model and Ohlson Model in Predicting Financial Distress of Manufacturing Companies in the Indonesia Stock Exchange. Journal of Accounting and Finance (IPJAF) 1(1): 51-63. www.ipjaf.omjpalpha.com.

Kristanti, F. T., Sri, R., and Akhmad, N. (2016). The Determinant of Financial Distress on Indonesian Family Firm. Procedia - Social and Behavioral Sciences 219: 440-47.

Lau, A. (1987). A Five-State Financial Distress Prediction Model. Journal of Accounting Research 25(1): 127.

Liang, D., Chia, C. L., Chih, F. T., and Guan, A. S. (2016). Financial Ratios and Corporate Governance Indicators in Bankruptcy Prediction: A Comprehensive Study. European Journal of Operational Research 252(2): 561-72. http://dx.doi.org/10.1016/j.ejor.2016.01.012.

Madaleno, M., and Bărbuţă-Mişu, N. (2019). "The Financial Performance of European Companies: Explanatory Factors in the Context of Economic Crisis." Ekonomika 98(2): 6-18.

OECD. 2020. "The Impact of the Coronavirus (COVID-19) Crisis on Development Finance." Tackling coronavirus (COVID-19) Contributing to a global effort 100(6): 468-70. http://www.oecd.org/termsandconditions.

Ohlson, J. A. (1980). Financial Ratios and the Probabilistic Prediction of Bankruptcy. Journal of Accounting Research 18(1): 109.

Parliament, European et al. 2011. "Press Release IMF." (20120523): 32-33.

Restianti, T., and Linda, A. (2018). Accounting Analysis Journal The Effect of Financial Ratios on Financial Distress Conditions in Sub Industrial Sector Company. Accounting Analysis Journal 7(1): 25-33. https://journal.unnes.ac.id/sju/index.php/aaj.

See, L. F., and Shaakalya, P. (2019). An Analysis of Z-Scores \& Performance: Manufacturing Companies in Hong Kong. Asian Journal of Business and Management 7(2): 28-34.

Smrčka, L., Markéta, A., and Jaroslav, S. (2013). Reasons for the Failure to Implement Financial Rehabilitation Procedures in Insolvent Reality. Politicka Ekonomie 61(2): 188-208.

Steinker, S., Mario, P., and Kai, H. (2016). Inventory Management under Financial Distress: An Empirical Analysis. International Journal of Production Research 54(17): 5182-5207.

Taffler, R. J. (1983). The Assessment of Company Solvency and Performance Using a Statistical Model. Accounting and Business Research 13(52): 295-308.

Tesfamariam, Y. (2014). The Determinants of Financial Distress in the Case of Manufacturing Share Companies in Addis Ababa-Ethiopia. 1-86.

Thim, C. K., Yap, V. C., and Chai, S. N. (2011). Factors Affecting Financial Distress: The Case of Malaysian Public Listed Firms. Corporate Ownership and Control 8(4 D): 345-51.

Zmijweski, M. E. (1984). Methodological Issues Related to the Estimation of Financial Distress Prediction Models. Journal of Accounting Research 22: 59-82. 